\title{
STRATEGI PENGAMBILAN KEPUTUSAN PADA ORGANISASI
}

\author{
Sarah Aulia \\ 175100053P \\ Fakultas Komputer \\ sarahaulia.student@umitra.ac.id
}

\begin{abstract}
Suatu keputusan tidak dapat terlepas dalam kehidupan kita sehari - hari, karena kita selalu dihadapkan pada hal tersebut. Keputusan itu bersifat dari yang sederhana sampai pada keputusan yang amat rumit dan sulit. Contoh yang sederhana, pada saat kita baru bangun tidurpun kita sudah dihadapkan pada situasi yang diharuskan kita untuk mengambil keputusan, apakah kita akan segera mandi atau duduk duduk dahulu dan membaca koran pagi.

Seorang pemimpin organisasi harus mampu mengambil keputusan, walaupun banyak faktor lain yang sangat besar pengaruhnya terhadap keputusanya, karena seseorang pada saat tertentu sudah mengambil keputusan, tetapi hal ini bisa berbeda keputusan disaat yang lain. Karena sebagian fungsi terpenting dari seorang pemimpin adalah sebagai pengambil keputusan, sehingga keputusan yang diambil oleh seorang pemimpin sangat berkenan dan menentukan terhadap tindakan apa yang perlu dilaksanakan, siapa yang melakukan serta kapan, dimana, dan terkadang bagaimana tindakan itu dilaksanakan. Misalnya seorang presiden perlu melakukan keputusan siapa yang menjadi anggota kabinetnya ; seorang manager harus membuat keputusan tentang perlu tidaknya mengangkat pegawai tambahan, pembelian mesin baru, atau memberhentikan karyawanya. Karena suatu keputusan itu sangat penting maka kemampuan untuk membuat keputusan yang sangat tepat dan berkwalitas menjadi suatu hal yang mutlak harus dimiliki seorang pemimpin.
\end{abstract}

Kata Kunci : Pengambilan Keputusan, Tindakan, Manajemen. 
A. PENDAHULUAN

Pengambilan keputusan pada umumnya adalah memilih suatu jalur tindakan di antara beberapa alternatif yang tersedia melalui suatu proses mental dan berfikir yang logis. Ketika mencoba untuk membuat keputusan yang terbaik, seseorang harus menimbang sisi positif dan negatif dari setiap pilihan, dan mempertimbangkan semua alternatif. Untuk pengambilan keputusan yang efektif, seseorang harus mampu memprediksikan hasil dari setiap pilihan, dan berdasarkan pada semua item tersebut, menentukan pilihan mana yang terbaik untuk situasi tertentu. Pengambilan keputusan harus berdasarkan beberapa tahapan yang mungkin akan dilalui oleh pembuat keputusan. Tahapan tersebut bisa saja meliputi identifikasi masalah utama, menyusun alternatif yang akan dipilih dan seterusnya

Dasar-Dasar Pengambilan Keputusan

Menurut George R. Terry, dasar-dasar pengambilan keputusan adalah sebagai berikut :

1.Intuisi

Pengambilan keputusan yang berdasarkan intuisi atau perasaan bersifat subjektif, sehingga mudah terkena pengaruh.

2.Pengalaman

Pengambilan berdasarkan memiliki manfaat bagi pengetahuan praktis.

Karena pengalaman seseorang dapat memperkirakan keadaan sesuatu, dapat memperhitungkan

untung ruginya, baik buruknya keputusan yang akan dihasilkan.

3.Fakta

Pengambilan keputusan berdasarkan fakta dapat memberikan keputusan yang sehat, solid, dan

baik. Dengan fakta, maka tingkat kepercayaan terhadap pengambilan keputusan dapat lebih tinggi,

sehingga orang dapat menerima keputusan-keputusan yang dibuat itu dengan rela dan lapang dada.

4.Wewenang

Biasanya dilakukan oleh pimpinan terhadap bawahannya atau orang yang lebih tinggi kedudukannya kepada orang yang lebih rendah kedudukannya.

5.Rasional

Keputusan yang dihasilkan lebih objektif, logis, lebih transparan, konsisten untuk

memaksimumkan hasil atau nilai dalam batas kendala tertentu, sehingga dapat dikatakan

mendekati kebenaran atau sesuai dengan apa yang diinginkan. 


\section{B. PEMBAHASAN / STUDI KASUS \\ Di awal-awal tahun,} perusahaan Niketidak memiliki sumber dana untuk membeli sebuah pabrik atau mempekerjakan banyak karyawan. Modal yang dimiliki oleh Knight sangat kecil dan ia tidak bisa membeli sepatu dari Asia. Sebenarnya Nike termasuk hollow corporation karena tidak memiliki pabrik manufacture sendiri, Nike hanya perantara antara supplier dengan retailer.

Nike fokus pada menemukan inovasi sepatu terbaru. Kombinasi dari pekerja yang murah dan perkembangan pasar yang baik memungkinkan perusahaan untuk bersaing dalam research and development. Di awal 80an, Nike menjadi produsen sepatu atletik nomor 1 di dunia. Untuk memastikan bahwa supplier Nike memiliki kualitas yang tinggi, Knight menuntut mereka untuk mempunyai hubungan dengan perusahaan lainnya. Jika supplier percaya dan bekerja sama dengan Nike, Knight memastikan bahwa mereka akan puas dengan dirinya sendiri. Kemudian jika salah satusupplier menjadi sangat mahal, Nike bisa mengganti supplier dengan tetap menjaga kualitas yang ditetapkan.

Ditahun 1983, orang kepercayaan Knight melakukan kesalahan dalam pengelolaan Nike. Si pelaksana ini melihat celah untuk ekspansi ke pasar sepatu biasa. Data statistic mereka menunjukkan hampir $90 \%$ pembeli sepatu Nike tidak menggunakan sepatu tersebut untuk atletik. Mereka percaya bahwa sepatu casual akan diterima lebih baik oleh konsumen. Sayangnya, hal tersebut salah. Pendatang baru, Reebok, berkembang karena sepatu aerobic dan mengambil posisi Nike sebagai produsen sepatu atletik nomor satu, berdampak pada Nike untuk memberhentikan 350 karyawannya. Melihat perusahaannya mengalami kekacauan, Knight kembali ke posisinya. Knight memutuskan untuk mendapatkan kembali posisi produsen sepatu nomor satu melalui kecepatan penjualannya. Seperti biasanya, Nike memiliki anggaran iklan yang sangat kecil, kebanyakan dari promosinya dilakukan oleh para pengecernya. Knight sekarang mengubah pendekatannya dengan kampanye "Just Do It" lewat televisi nasional dan majalah. Di bawah image baru Knight, superstar seperti Michael Jordan dan Bo Jackson memberi merek sepatunya sendiri, kampanye "Air Jordan" dan "Bo Knows" menunjukkan pada konsumen bahwa atlet terbaik di dunia memakai Nike.

Bagaimanapun suksesnya Nike, mereka akan selalu 
menghadapi kompetisi. Reebok adalah industri nomor dua yang selalu menunggu kesempatan untuk menjadi nomor satu lagi. Jaringan supply di Asia sekarang digunakan oleh pesaing Nike, tidak lama setelah perusahaan mendapat keuntungan produksi. Jika Nike melanjutkan

perkembangannya, Phil Knight dan staffnya harus melanjutkan untuk mengembangkan inovasi sepatu terbaru yang sesuai dengan image atletik.

Nike adalah produsen sepatu nomor satu di dunia. Dengan permodalan yang sedikit, Nike tidak mampu untuk membuat iklan untuk produknya. Nike kemudian hanya menggunakan image dari atlet terkenal untuk menarik minat konsumen. Selain itu untuk menekan biaya yang besar, Nike membeli sepatu dari supplier Asia. Para pekerja Asia yang terkenal murah bisa menekan harga yang ditawarkan supplier sehingga Nike bisa membeli dengan harga yang lebih murah.

Sebagai contoh adalah supplier Nike yang berasal dari Indonesia yaitu PT.Pratama Abadi Industri. PT. Pratama Abadi Industri adalah perusahaan yang bergerak dalam bidang manufaktur sepatu lari (running shoes). Perusahaan ini memproduksi berbagai tipe running shoes dalam berbagai jenis ukuran baik untuk anak-anak maupun orang dewasa. Spesifikasi dari tiap tipe sepatu telah diberikan oleh pihak Nike untuk kemudian diproduksi oleh PT. Pratama abadi Industri sesuai dengan syarat spesifikasi yang telah ada. Hasil produksi yang telah dihasilkan oleh PT. Pratama abadi Industri, tidak boleh dipasarkan di dalam negeri. Semua hasil produksi yang telah ada merupakan hak dari pihak Nike yang ada di Beverton (USA) untuk kemudian akan diekspor lagi ke negara lain, seperti Perancis, swedia, India, Belgia, Kanada, USA, Afrika

Selatan, Argentina, Uruguay, Chillie.

Nike sangat memegang kendali karena mempunyai hak untuk memutuskan kerjasama bila harga dari supplier terlalu mahal, hal ini bisa berdampak buruk bagi pekerja karena mereka tidak bisa menuntut kehidupan yang lebih baik dengan peningkatan tunjangan pekerja otomatis akan menambah biaya produksi yang mengakibatkan harga yang lebih mahal.Seperti yang terjadi di China, Vietnam, Indonesia dan Meksiko. Nike dikritik karena berusaha menutupi kondisi kerja yang buruk serta eksploitasi buruh. Nike juga adalah perusahaan besar yang tidak memiliki pabrik. Karena mereka lebih senang untuk outsourcing 
$\begin{array}{lr}\text { kebutuhan-kebutuhan } & \text { mereka } \\ \text { terutama kepada } & \text { sektor } \\ \text { informal, ataupun } & \text { perusahaan } \\ \text { lainnya, } & \text { sehingga } \\ \text { mengefisienkan } & \text { dan } \\ \text { meminimalisir } & \text { ongkos } \\ \text { produksi. } & \end{array}$

Knight tidak mampu mendelegasikan tugas dengan baik, sehingga di tahun 1983 Nike mengalami kemunduran karena tidak tepatnya perencanaan dari pelaksana yang dipercaya oleh Knight waktu itu. Waktu itu pengelola yang dipercaya Knight mengubah image Nike dari sepatu atletik menjadi sepatu kasual. Padahal saingannya Reebok lebih dahulu mengembangkan sepatu untuk aerobik, sehingga konsumen lebih percaya pada Reebok. Nike membutuhkan perencanaan baru untuk mengembalikan posisi Nike sebagai produsen sepatu nomor satu dengan penjualan yang secepatnya.

\section{ID SECURITY}

QWTD4452377-ASP-5244107

\section{KESIMPULAN}

Strategi Nike dalam membuat image yaitu dengan mensponsori seorang atlet atau suatu klub olahraga sehingga akan timbul image bahwa Nike dipakai oleh para atlet terkenal, hal ini tidak dilakukan oleh saingannya seperti Reebok yang justru hanya mensponsori suatu event olahraga saja. Disinilah pembuktian kekuatan merek dagang. Banyaknya masalah ataupun konflik yang terpublikasi, tidak akan membuat kosumen beralih ke merek lain. Hal ini karena ikatan psikologis antara Nike dengan konsumen fanatiknya telah terjadi, selebihnya, biarlah konsumen yang menilai.

Krisis yang dialami Nike pada tahun 1983 tak lepas dari proses pertumbuhan organisasi. Menurut Lary Greiner ada 5 tahap pertumbuhan organisasi, 1) kreativitas, 2) pengarahan,

3) pendelegasian, 4) koordinasi, dan 5) kerja sama. Nike mengalami krisis disaat tahap pendelegasian dimana Knight tidak melakukan kontrol yang ketat sehingga keputusan bawahannya membawa dampak bagi Nike. Knight kemudian melakukan terobosan kilat untuk membentuk kembali brand image dari Nike. Menurut Agyris "intervensi merupakan suatu aktivitas masuk ke dalam sistem relationship yang berjalan, baik diantara individu, kelompok, maupun organisasi, dengan tujuan membantu menuju suatu perubahan yang sukses" Dalam intervensi, terkadang perlu mendatangkan konsultan dari luar organisasi, tetapi intervensi terbanyak dapat 
dilakukan oleh managemen internal. Apa yang dilakukan oleh Knight merupakan intervensi dari manajemen internal. Marketing differentiation strategy mencoba menciptakan kesetiaan para pelanggan dengan cara memenuhi kebutuhan tertentu secara khusus. Organisasi tersebut mencoba menciptakan kesan yang menguntungkan bagi produk-produknya melalui iklan, segmentasi pasar, dan harga yang bersaing. Hal tersebut salah satu strategi yang dilakukan oleh Knight dengan menciptakan produk baru sesuai kebutuhan konsumen yang tidak lepas dari image olah raga.

\section{E. DISKUSI}

Nike sebenarnya memiliki posisi yang sedikit lemah bila dihadapkan dengan retailer. Keuntungan Nike didapat dari penjualan ke retailer. Retailer tentunya akan bersaing dengan retailer lain dengan harga termurah, hal ini dapat mengancam Nike karena dengan hal tersebut maka retailer akan menekan Nike untuk menjual sepatunya dengan lebih murah.

\section{F. REFERENCE}

[1] O. M. Febriani and A. S. Putra, "Sistem Informasi Monitoring
Inventori Barang Pada Balai Riset Standardisasi Industri Bandar Lampung," J. Inform., vol. 13, no. 1, pp. 90-98, 2014.

[2] A. S. Putra, "Paperplain: Execution Fundamental Create Application With Borland Delphi 7.0 University Of Mitra Indonesia," 2018.

[3] A. S. Putra, "2018 Artikel Struktur Data, Audit Dan Jaringan Komputer," 2018.

[4] A. S. Putra, "ALIAS MANAGER USED IN DATABASE DESKTOP STUDI CASE DB DEMOS."

[5] A. S. Putra, "COMPREHENSIVE SET OF PROFESSIONAL FOR DISTRIBUTE COMPUTING."

[6] A. S. Putra, "DATA ORIENTED RECOGNITION IN BORLAND DELPHI 7.0."

[7] A. S. Putra, "EMBARCADERO DELPHI XE 2 IN GPUPOWERED FIREMONKEY APPLICATION."

[8] A. S. Putra, "HAK ATAS KEKAYAAN INTELEKTUAL DALAM DUNIA TEKNOLOGY BERBASIS REVOLUSI INDUSTRI 4.0."

[9] A. S. Putra, "IMPLEMENTASI PERATURAN PERUNDANGAN UU. NO 31 TAHUN 2000 TENTANG DESAIN INDUSTRI BERBASIS INFORMATION TECHNOLOGY."

[10] A. S. Putra, "IMPLEMENTATION OF PARADOX DBASE."

[11] A. S. Putra, "IMPLEMENTATION OF TRADE SECRET CASE 
STUDY SAMSUNG MOBILE PHONE."

A. S. Putra, "IMPLEMENTATION

PATENT FOR APPLICATION WEB BASED CASE STUDI WWW. PUBLIKLAMPUNG COM."

[13] A. "IMPLEMENTATION SYSTEM FIRST TO INVENT IN DIGITALLY INDUSTRY."

[14] A. S. Putra, "MANUAL REPORT \& INTEGRATED DEVELOPMENT

ENVIRONMENT BORLAND DELPHI 7.0."

[15] A. S. Putra, "PATENT AS RELEVAN SUPPORT RESEARCH."

[16] A. S. Putra, "PATENT FOR RESEARCH STUDY CASE OF APPLE. Inc."

[17] A. S. Putra, "PATENT PROTECTION FOR APPLICATION INVENT."

[18] A. S. Putra, "QUICK REPORT IN PROPERTY PROGRAMMING."

[19] A. S. Putra, "REVIEW CIRCUIT LAYOUT COMPONENT

REQUIREMENT ON ASUS NOTEBOOK."

[20] A. S. Putra, "REVIEW TRADEMARK PATENT FOR INDUSTRIAL TECHNOLOGY BASED 4.0."

[21] A. S. Putra, "TOOLBAR COMPONENT PALLETTE IN OBJECT ORIENTED PROGRAMMING."

[22] A. S. Putra, "WORKING DIRECTORY SET FOR PARADOX 7."
[23] A. S. Putra, "ZQUERY CONNECTION IMPLEMENTED PROGRAMMING STUDI CASE PT. BANK BCA Tbk."

[24] A. S. Putra, D. R. Aryanti, and I. Hartati, "Metode SAW (Simple Additive Weighting) sebagai Sistem Pendukung Keputusan Guru Berprestasi (Studi Kasus: SMK Global Surya)," in Prosiding Seminar Nasional Darmajaya, 2018, vol. 1, no. 1, pp. 85-97.

[25] A. S. Putra and O. M. Febriani, "Knowledge Management Online Application in PDAM Lampung Province," in Prosiding International conference on Information Technology and Business (ICITB), 2018, pp. 181-187.

[26] A. S. Putra, O. M. Febriani, and B. Bachry, "Implementasi Genetic Fuzzy System Untuk Mengidentifikasi Hasil Curian Kendaraan Bermotor Di Polda Lampung," SIMADA (Jurnal Sist. Inf. dan Manaj. Basis Data), vol. 1, no. 1, pp. 21-30, 2018.

[27] A. S. Putra, H. Sukri, and K. Zuhri, "Sistem Monitoring Realtime Jaringan Irigasi Desa (JIDES) Dengan Konsep Jaringan Sensor Nirkabel," IJEIS (Indonesian J. Electron. Instrum. Syst., vol. 8, no. 2, pp. 221-232.

[28] D. P. Sari, O. M. Febriani, and A. S. Putra, "Perancangan Sistem Informasi SDM Berprestasi pada SD Global Surya," in Prosiding Seminar Nasional Darmajaya, 2018, vol. 
E TUGAS 2 - Manajemen Sains

1, no. 1, pp. 289-294. 